\title{
BRANCA DE NEVE E O HOMEM LETRADO
}

\author{
Adriana Pastorello Buim Arena ${ }^{1}$ \\ (Dhttps://orcid.org/0000-0002-8355-0221 \\ Juliana Chieregato Pedro ${ }^{2}$ \\ (Dhttps://orcid.org/0000-0003-2261-0101
}

Resumo: Contos de Fadas, chamados também de Histórias Fantásticas ou Contos Mágicos, são narrativas que fazem parte do literário folclórico, propagadas através de gerações. Além de expressarem a cultura de um povo e de uma época sua propagação é fundamental para o desenvolvimento coletivo e social dos homens. Este trabalho visa analisar como a cultura do homem letrado produz compreensões diversas a partir da obra literária Branca de Neve, escrita pelos irmãos Jacob e Wilhelm Grimm. Para tanto, foi utilizada a versão brasileira que consta no livro Contos de Grimm, traduzido por Heloísa Jahn e publicado em 1996 pela editora Companhia das Letrinhas. No decorrer da análise são demonstradas três configurações de olhares para uma obra escrita: seus aspectos gráficos, a relação intersemiótica entre o texto e a ilustração, e sua intertextualidade. Cada uma destas análises, por elas mesmas, indicou diferentes graus de apropriações da cultura literária. Por meio de uma pesquisa documental baseada especialmente nas análises psicanalíticas de Bettelheim, procuramos desvendar como o contato com as produções escritas, acadêmicas ou literárias do referido autor, pode dar ao conto uma interpretação única e singular em relação à madrasta, à enteada e suas disputas, como também colocar em discussão o entendimento do conceito de homem letrado..

Palavras-chave: Literatura infantil. Conto de fadas. Homem letrado.

\footnotetext{
${ }^{1}$ Doutora em Educação pela Unesp - Campus de Marília. Professora da Faculdade de Educação da Universidade Federal de Uberlândia. E-mail: dricapastorello@gmail.com

${ }^{2}$ Graduada em Pedagogia pela Faculdade de Educação da Universidade Federal de Uberlândia. E-mail: juchieregato@hotmail.com
} 


\title{
SNOW WHITE AND THE CULTURED MAN
}

\begin{abstract}
Fairy tales, also called Fantastic Stories or Magic Tales, are narratives that are part of the folkloric literary, propagated through generations. In addition to expressing the culture of a people and an time, its propagation is fundamental for the collective and social development of men. This work aims to analyze how the culture of the cultured man produces different understandings from the literary work Snow White, written by the brothers Jacob and Wilhelm Grimm. For this purpose, the Brazilian version contained in the book Grimm's Tales, translated by Heloísa Jahn and published in 1996 by the publisher Companhia das Letrinhas, was used. In the course of the analysis, three configurations of looks for a written work will be demonstrated: its graphic aspects, the intersemiotic relationship between the text and the illustration, and its intertextuality. Each of these analyzes, by themselves, will indicate different degrees of appropriations of the literary culture. Through documentary research based especially on Bettelheim's psychoanalytical analyzes, we seek to discover how contact with the author's written, academic or literary productions can give the story a unique and singular interpretation in relation to the stepmother, stepdaughter and her disputes, but also to discuss the understanding of the concept of cultured man.
\end{abstract}

Keywords: Children's literature. Fairy tale. Cutured man.

\section{BLANCANIEVES Y EL HOMBRE CULTO}

Resumen: Los cuentos de hadas, también llamados Cuentos fantásticos o Cuentos mágicos, son narraciones que forman parte de la literatura folclórica, propagada a través de las generaciones. Además de expresar la cultura de un pueblo y una época, su propagación es fundamental para el desarrollo colectivo y social de los hombres. Este trabajo tiene como objetivo analizar cómo la cultura del hombre culto produce diferentes interpretaciones de la obra literaria Blancanieves, escrita por los hermanos Jacob y Wilhelm Grimm. Para este propósito, se utilizará la versión brasileña contenida en el libro Cuentos de Grimm, traducido por Heloísa Jahn y publicado en 1996 por la editorial Companhia das Letrinhas. En el curso del análisis, se demuestran tres configuraciones de miradas para una obra escrita: sus aspectos gráficos, la relación intersemiótica entre el texto y la ilustración, y su intertextualidad. Cada uno de estos análisis, por sí mismos, indicó diferentes grados de apropiación de la cultura literaria A través de la investigación documental basada especialmente en los análisis psicoanalíticos de Bettelheim, buscamos desentrañar cómo el contacto con las producciones escritas, académicas 0 literarias del autor puede dar a la historia una interpretación única y singular en relación con la madrastra, la cocinera y sus disputas, como también se discutió la comprensión del concepto de hombre culto.

Palabras clave: Literatura infantil. Cuento de hadas. Hombre culto 


\section{Introdução}

Este ensaio não tem como propósito colocar na pauta da discussão do professor a importância da literatura para a formação das crianças, porque isso parece ser consenso. Ao contrário disso, desejamos refletir sobre a necessidade de o professor percorrer caminhos sempre em busca de maior inserção, sua e das crianças, no mundo da cultura letrada, em todas as áreas, mas aqui abordaremos especificamente os contos de fadas. Devido a todos os problemas políticos e estruturais que a educação enfrenta no Brasil, nem sempre os docentes conseguem ser as pessoas letradas em um nível condizente com o que é exigido pela profissão. Do professor se espera que tenha uma estreita relação com a escrita e com a leitura. Seu acervo cultural precisa ser amplo para que das aulas ministradas vazem opções de escolhas literárias para os alunos. A abundância é necessária; a profundidade da discussão literária também.

O leitor que escolheu ler este ensaio se interessa por, pelo menos, dois temas: os contos de fadas e quem sabe, o conceito de letramento. Portanto, fazem-se necessárias algumas explicações para que possa tomar a decisão de continuar lendo ou não.

A primeira discussão é sobre a não adesão ao conceito de letramento. Este conceito tem uma longa história e continua, no processo vivo da linguagem, ganhando ainda muitos significados e sentidos. 0 propósito deste texto não é fazer uma recuperação dos sentidos já empregados nesse conceito - embora consideremos essa uma tarefa importante -, mas mostrar ao leitor que o tomaremos em um sentido particular e específico, aquele de pessoa letrada, tão usado em gerações precedentes. Não assumiremos o termo letramento, porque este parece sempre precisar de um adjetivo complementar - letramento literário, letramento matemático, letramento digital, letramento crítico e tantos outros que ainda estão por vir. A excessiva adjetivação, a nosso ver, esvazia o conceito, o banaliza e desvia seu foco da produção cultural escrita para conteúdos escolares. Neste ensaio, retomaremos o conceito de homem letrado, leitor letrado, pessoa letrada, mundo letrado. Adjetivo correlato ao mundo da escrita. Não usaremos a palavra substantivada letramento. Por letrados, entendemos os homens, sempre em transformação, em seus mergulhos profundos no mundo da cultura escrita para se encharcarem de saberes e valores veiculados pelas letras, pelas palavras, um processo infinito e inacabado. Também não usaremos o conceito de letramento como sinônimo de alfabetização. Nela pode-se ou não iniciar uma criança no mundo da cultura 
escrita. Esse processo é amplo, situado historicamente, e envolve a cultura das sociedades que produziram materiais escritos. Assim, também, consideramos que este conceito se remete às letras, à escrita e não à oralidade (CHARAUDEAU; MAINGUENAU, 2002).

Consegue-se mergulhar em diversos oceanos. Quanto mais o homem se banhar nessa diversidade, tanto mais se transformará, já dizia Heráclito de Éfeso. Esta metáfora, que percorrerá o ensaio todo, nos ajuda a mostrar um mergulho possível e profundo no conto de fadas, Branca de Neve, sob a perspectiva de um desses oceanos possíveis, o da psicanálise. Nenhum texto é compreendido por ele mesmo, há uma relação imbricada com outros contextos e textos que tecem nossa forma de ver e olhar sua materialidade, fazer dele um dito, torná-lo vivo, potencialmente discursivo. Tentaremos mostrar o grau elevado em que está Bettelheim (1980) em seu mergulho no oceano da psicanálise e do conto Branca de Neve no processo de imersão na cultura letrada.

A segunda explicação necessária é sobre os sentidos e significados dos contos de fadas, a partir de alguns autores. Chamados de Histórias Fantásticas ou Contos Mágicos são contos que fazem parte do literário folclórico em diversas culturas. Dentro da civilização ocidental temos como destaque a obra dos alemães Irmãos Grimm, ávidos estudiosos da cultura mitológica germânica e francesa, dedicados a catalogar diversas histórias infantis passadas, até então, exclusivamente de forma oral (ROBINSON, 2004).

Contudo, a própria definição precisa do que é um Conto de Fadas pode ter diversas interpretações de acordo com a inclinação do autor, derivada de seu singular processo de apropriação por meio da escrita. Para Tolkien (2013, p. 12), em seu ensaio Sobre Contos de Fadas contido no livro Árvore e Folha, podemos ver sua visão simples acerca do que pode ser classificado como um Conto de Fadas: "Por ora só direi isto: um "conto de fadas" é aquele que toca ou usa o Reino Encantado, qualquer que seja seu propósito principal, sátira, aventura, moralidade, fantasia." Podemos concluir que, para o autor, os Contos de Fadas precisam ter contato com o que a cultura considera mágico ou fantástico. Para Tolkien (2013) o propósito principal não é o mais importante para que uma história seja considerada um Conto de Fadas, que pode conter um ensinamento ou ser um mero entretenimento.

Lane (1993, p. 15), por sua vez, tem uma conceituação mais completa em seu livro Picturing a Rose: A Way of Lookingat Fairy Tales: 
Minha própria definição de conto de fadas é mais ou menos assim: um conto de fadas é uma história literária ou folclórica - que tem uma sensação do numinoso, do sentimento ou sensação do sobrenatural ou do misterioso. Mas, e isso é crucial, é uma história que acontece no passado, e uma história que não está ligada a nenhum detalhe específico. Se isso acontece 'no começo do mundo', então é um mito. Uma história que nomeia uma pessoa 'real' específica é uma lenda (mesmo que contenha uma ocorrência mágica). Uma história que acontece no futuro é uma fantasia. Contos de fada às vezes são espirituais, mas nunca religiosos.

Ambos autores estão de acordo em relação à presença do que é mágico e sobrenatural em um Conto de Fadas, mas Lane (1993) vai além do que foi definido por Tolkien (2013), especificando que a trama deve acontecer no passado, porém com o cuidado de não o confundir com lendas ou mitos. A ocorrência do conto no tempo passado lembra-nos que possuem algum ensinamento em sua conclusão, que poderia ser considerado como um conselho para uma criança em desenvolvimento, ainda que não fique claro se uma lição de moral é ou não um pré-requisito, para Lane, nos Contos de Fadas (1993).

Bettelheim (1980, p. 14), mergulhado no oceano da psicologia, se interessa em utilizar os contos de fadas em terapias com crianças:

\begin{abstract}
Quanto mais tentei entender a razão de estas histórias terem tanto êxito no enriquecimento da vida interior da criança, tanto mais percebi que esses contos, num sentido bem mais profundo do que outros tipos de leitura, começam onde a criança realmente se encontra no seu ser psicológico e emocional. Falam de suas pressões internas graves de um modo que ela inconscientemente compreende e - sem menosprezar as lutas interiores mais sérias que o crescimento pressupõe - oferecem exemplos tanto de soluções temporárias quanto permanentes para dificuldades prementes.
\end{abstract}

Nossa intenção, até o momento é mostrar como o percurso interpretativo de um texto pode ser diverso, a depender dos graus de impregnação pela cultura letrada de diversas áreas do saber, por aquele que expressa sua compreensão sobre um discurso, neste caso, sobre o texto literário. Tolkien (2013) e Lane (1993) mergulham em oceanos de saberes diferentes dos de Bettelheim (1980), por isso, suas formas de ver o mundo e entender um discurso não são convergentes. Não existe, nos registros gráficos deixados por homens que produziram cultura, o certo ou o errado, mas existe o caminho percorrido e as ideias reelaboradas. Quanto mais um nadador treina mergulho, mais consegue prender a respiração e permanecer dentro da água; o tempo ajuda a escolher de dentro aspectos não vistos de fora. A interpretação que faz Bettelheim (1980) dos contos de 
fadas pode não fazer sentido algum para outros leitores também da área de psicologia, que fazem mergulhos profundos em outros oceanos, que não os de Freud.

Independente de qual definição seja escolhida como favorita, sabemos que os Contos de Fadas ocidentais, com a forma que os conhecemos atualmente, surgiram primeiramente na Europa, principalmente na Alemanha e França da era Vitoriana (LUBETSKY, 1989) em um momento da história marcado pela ascensão da burguesia e de uma Igreja Católica em contrarreforma, tornando clara a influência da "Moral Vitoriana", caracterizada por intensas noções de moralidade conservadora, incluindo a repressão da sexualidade (SCHINEIDER; TOROSSIAN, 2009). Isso explicaria a constante presença de personagens femininos caracterizadas como seres quase angelicais em sua inocência e nobreza, mostrando o ideal de mulher daquela época, algo que poderemos verificar em Branca de Neve, conto analisado neste ensaio.

Dadas as duas explicações necessárias, podemos partir para a análise do conto.

\section{Branca de Neve}

O texto escolhido para análise encontra-se na obra Contos de Grimm: Branca de Neve, de Jacob e Wilhelm Grimm, ilustrado por Elzbieta Gaudasinska, traduzido por Heloísa Jahn e editado em 1996 pela Companhia das Letrinhas. De forma abreviada, apontaremos as características da personagem principal e suas relações com os demais personagens, destacaremos alguns aspectos gráficos e linguísticos do texto, assim como os aspectos gráficos da ilustração e, por fim, ressaltaremos aspectos intertextuais que a obra apresenta.

A personagem principal é uma jovem princesa, órfã de pai e de mãe ainda criança no início da história. Cheia de inocência, não podia perceber qualquer um dos males do mundo, o que a tornava vulnerável à madrasta ciumenta, vaidosa e muito invejosa, que desejava ser a mais bela. Branca de Neve era sonhadora, gentil e romântica, mas estava disposta a trabalhar duro se fosse necessário para ganhar seu sustento. Ao crescer de sua primeira infância, Branca de Neve foi descrita como "a mais bela em toda a terra”, por uma beleza que ninguém possuía, em contraponto à beleza da rainha, deixando claro o entendimento de que a mera beleza física não bastava como atributo a uma mulher, devendo ela também possuir sentimentos nobres em seu coração para merecer o título de maior beleza dentre todas as outras. No entanto, a bondade inerente de Branca de 
Neve e sua pureza também inspiravam proteção e admiração em todos os outros personagens masculinos da trama: o caçador, que a admirava tal qual a uma figura angelical e por isso recusou-se a matá-la; os sete anões, que deixaram-na morar em sua casinha com o propósito de ter alguém que cuidasse dos afazeres domésticos, como faria uma mãe para seus filhos; e por fim o belo e jovem príncipe, que enxergava sua beleza exterior, primeiramente, e a desejou então como esposa.

No que se refere aos aspectos gráficos e linguísticos do texto, ao que nos parece, o uso das figuras de linguagem o faz propício para o público infantil. Nessa tradução podemos, ao lê-lo, verificar o cuidado com a escolha de palavras próprias do universo infantil. Logo no início temos o uso de uma catacrese (termo que existe devido à falta de uma palavra específica para nomear algo) com o intuito de explicar como é o cair da neve para uma criança, assumindo que ela nunca a tenha visto. Assim aparece no início do conto: "Uma vez, no pior inverno, com a neve caindo do céu feito um monte de peninhas e plumas [...]" (GRIMM; GRIMM, 1996, p. 47).

É possível notar ainda neste trecho o uso do diminutivo, mais uma vez simbolizando que o texto é, de fato, voltado para crianças. Ao seguirmos com a história temos o desejo da Rainha Mãe, ao picar o dedo em uma agulha: "Ah, se eu pudesse ter um filhinho, um filhinho branco feito a neve, corado feito sangue, e com o cabelo preto feito o ébano dessa janela!” (GRIMM; GRIMM, 1996, p. 47). Percebe-se o uso de comparações (figura de linguagem parecida com uma metáfora, mas com um conectivo que deixa essa relação comparativa explícita) para descrever a aparência desejada ao bebê da Rainha: branco feito a neve, corado como sangue e cabelos escuros como a madeira de sua janela. Esta comparação é tão tocante que a mãe, ao ver sua bebê nascida, decide chamá-la de Branca de Neve: tão branca quanto à neve.

Na sequência, Branca de Neve tornou-se órfã de pai e mãe e ficou sob a tutela de uma madrasta narcisista e praticante de magias obscuras, dona de um espelho que só dizia a verdade. Uma célebre e importantíssima fala da madrasta é responsável por quase toda a ação. Normalmente, os diálogos no livro encontram-se na forma padrão da língua, com uso de dois pontos e travessão, contudo, os diálogos entre madrasta e espelho mágico possuem um formato de poesia, talvez denotando a aparência etérea da interação: 
Espelho, meu espelhinho

Me diga: no meu reino

Quem é a mulher mais bonita?

0 espelho respondeu:

Querida rainha, aqui dentro a mais bonita é você,

Mas como Branca de Neve não há.

(GRIMM; GRIMM, 1996, p. 48).

Mais uma vez temos o emprego do diminutivo em espelhinho como forma de amenizar a história para o público infantil. É risório pensar que uma rainha nobre e narcisista falaria com este tom carinhoso com seu servo, o espelho, ainda que ele fosse essencial para ela. A profunda vaidade da Rainha má levava-a a repetir muitas vezes essa pergunta; esse recurso de escrita leva o leitor/ouvinte a familiarizar-se com o enredo. Essa constante repetição gera uma previsão de acontecimentos ao mesmo tempo em que abre portas para surpresas ainda maiores.

Ao descobrir que Branca de Neve seria mais bela do que ela, o autor passa a utilizar diversas figuras de linguagem para descrever o desespero da madrasta:

A rainha deu um pulo e ficou amarela, depois verde de tanta inveja. A partir daquele momento não pode mais ver Branca de Neve sem sentir o coração dar voltas no peito de tanto ódio que sentia. A inveja era tamanha que o orgulho tomou conta de seu coração como erva daninha [...] (GRIMM; GRIMM, 1996, p. 48).

Com o uso das figuras de linguagem podemos ter uma visão bastante clara do martírio da rainha. Ficou amarela, como se estivesse sendo consumida pela doença da inveja; depois verde. Sentia-se tão mal que o coração dava voltas no peito. As perífrases ficar amarelo, assim como verde de inveja são de emprego bastante comum no Brasil para descrever uma aparência doente e o sentimento de inveja extrema, mostrando o cuidado com a tradução ao utilizar termos do cotidiano da língua portuguesa. 0 coração dar voltasé uma metáfora (designação de um objeto ou qualidade mediante uma palavra que designa outro objeto ou qualidade que tem com o primeiro uma relação de semelhança) para um ataque de pânico, quando o coração dispara em uma crise de ansiedade.

Podemos ressaltar também o uso de comparações - bela como o dia - pois é interessante destacar a preferência dos autores em comparar a beleza de Branca de Neve com a perfeição da natureza, uma clara referência de superioridade, pois não é encontrada em nenhuma outra pessoa para igualar-se a ela nesse quesito. Por ser a protagonista ainda uma criança, o uso de hipérboles (ênfase expressiva resultante do 
exagero da significação linguística) é empregado tanto para interagir melhor com a linguagem infantil, quanto para exprimir mais claramente o acontecimento. Eis alguns exemplos: "se fosse possível ia fazer questão de olhar atrás de cada folha de árvore; morta de cansaço; Branca de Neve estava morrendo de vontade de comer a maçã” (GRIMM; GRIMM, 1996, p. 50 - 60).

Essa figura de linguagem aproxima o leitor do desespero da pobre criança naquela situação desconhecida, e, com isso, gera também sentimentos no ouvinte, tais como a indagação interior de qual seria sua própria reação num momento semelhante. Também o uso de aliteração (repetição de fonemas idênticos ou parecidos no início de várias palavras na mesma frase ou verso, visando obter efeito estilístico na prosa poética e na poesia) faz diferença na estruturação do conto: “[...] faquinha... colherinha... garfinho... pratinho... caminhas... esticadinho [...]" (GRIMM; GRIMM, 1996, p. 50). 0 som provocado pelas palavras, intencionalmente diminutivas, reforça a ideia de pequenez da casinha e influencia a imaginação na proporção em que ela criará os objetos citados, sendo esse um bom recurso para aprimorar as cenas mentais criadas durante a leitura. Facilita, por consequência, o trabalho que as crianças terão, pois a repetição da forma ajuda que as mentes estejam mais atentas.

Na parte em que os anões são apresentados ao retornarem à casa e encontrarem Branca de Neve, temos um uso sequencial de diminutivos com o intuito de descrever o quão pequeninos eram os anões:

- Quem se sentou na minha cadeirinha? - perguntou o primeiro.

- Quem comeu no meu pratinho? - falou o segundo.

- Quem pegou um pedaço do meu pãozinho - disse o terceiro.

- Quem tomou um pouco da minha sopinha? - espantou-se o quarto.

- Quem sujou meu garfinho? - interrogou o quinto.

- Quem usou minha faquinha? - quis saber o sexto.

- Quem bebeu no meu copinho? - preocupou-se o sétimo (GRIMM; GRIMM, 1996, p. 52).

De forma divertida, o autor usa esta aliteração tanto para apresentar os sete anões, quanto para descrever a sua pequenez ao repetir continuamente os diminutivos. Semelhante a itens já explicados, o polissíndeto (uso repetitivo e excessivo de algumas conjunções entre as orações de modo sequencial) apresentado na sequência de falas da página 52, busca trazer uma imagem objetiva e proporcionar uma previsão dos acontecimentos. 
A esta altura do enredo o leitor já sabe a resposta para todas as perguntas apresentadas, no entanto, esse momento de espera gera certa ansiedade sobre qual será a reação dos anões ao descobrirem o culpado por tais atos. Também serve com o propósito de se fazer conhecer os novos personagens, já que esses até agora não haviam se apresentado, portanto não seria possível fazer previsões se não fosse apresentada alguma característica daquele seleto grupo.

Anáforas (repetição da mesma palavra ou grupo de palavras no princípio de frases ou versos consecutivos) têm seu espaço reservado no texto e podem ser percebidas, dentre outros lugares, nas seguintes transcrições: "uma maçã envenenada, uma maçã envenenadíssima e estava morta e bem morta, e morta continuou” (GRIMM; GRIMM, 1996, p. 58 - 60). A repetição intencional das palavras maçã envenenada e morta testificam a seriedade daquela colocação, evidenciando ser uma parte muito importante para o enredo e que não pode ser ignorada. Ao considerar o público-alvo das publicações - crianças - que rapidamente entram em dispersão, tal figura de construção possui considerável importância para uma compreensão plena da sequência do conto.

Por fim, a prosopopeia (figura pela qual o orador ou escritor empresta sentimentos humanos e palavras a seres inanimados) fez-se presente também, "as aves também vieram olhar e choraram ao ver Branca de Neve” (GRIMM; GRIMM, 1996, p. 61). Como costume geral, os contos de fadas adotam ações humanas para seres não-humanos. Nesse texto, podemos deduzir que para além de fins tradicionais, o sentimento das aves apresenta ligação com a beleza, interior e exterior, de Branca de Neve que a aproximava muito da natureza e, por isso, também os animais sentiam essa perda.

0 texto segue este padrão de escrita infantil até seu final. 0 uso do diminutivo se estende por toda trama. A sinestesia (cruzamento de sensações; associação de palavras ou expressões em que ocorre combinação de sensações diferentes numa só impressão), contudo, aparece frequentemente ao descrever Branca de Neve como uma pessoa doce, fazendo referência ao seu jeito inocente e a sua beleza de adolescente. Não se trata, portanto, de um livro complicado, cheio de metáforas e alusões para que a criança interprete a seu modo. A história é direta, simples, com descrições que não fogem ao universo da literatura infantil. 0 autor preza pela facilidade e clareza no entendimento da história, sendo ela o foco principal da obra, ainda que para leitores adultos seja possível encontrar diversas interpretações para a escolha de palavras. 
Com toda esta análise linguística da construção do texto, não se deseja insinuar que esse conhecimento deve ser obrigatoriamente dado a criança. Evidentemente, elas não leem Branca de Neve para encontrar figuras de linguagem ou figuras de pensamento. Contudo, deseja-se indicar que neste tipo de análise se encontra um determinado grau de apropriação da linguagem escrita no reconhecimento de um texto literário, que normalmente é rico em figuras de linguagem. Esse, entre outros que veremos a seguir, é um mergulho necessário para verticalizar o entendimento de critérios que poderiam nos levar às obras literárias de grande qualidade.

No século XXI, a maioria dos livros infantis é ilustrada. Tem-se outro oceano de filigranas para mergulhar, o dos aspectos gráficos da ilustração. 0 conto escolhido foi ilustrado por Elżbieta Gaudasińska-Borowska. 0 traço estilizado e a gama particular de cores de sua palheta, constituída de ocres, verdes pálidos, terracotas, evoca a Europa medieval, tempo e espaço das narrativas recolhidas pelos dois irmãos. 0 livro apresenta características bem peculiares, com bela capa, papel de excelente qualidade, letras de tamanho adequado para um leitor principiante.

As ilustrações aparecem em página inteira ou meia página, o que nos remete ao entendimento da preocupação editorial com o leitor infantil. Um detalhe a se destacar é o cuidado na elaboração das ilustrações à margem de cada conto que, além do toque mimoso, atuam como um resumo pictórico, elemento valioso na constituição de habilidades necessárias ao ato da leitura. Apesar de o conto possuir poucas ilustrações, temos ilustradas as partes essenciais para a sua compreensão, existindo assim uma relação entre as imagens e a história que o texto quer narrar, mostrando sua característica de obra ilustrada.

As imagens apresentadas durante a narrativa nos permitem visualizar como foi pensada e desenhada a história em questão. A ilustração permite com que o leitor mergulhe no mundo simbólico e cultural de forma intensa. No entanto, a ilustração pode ter várias outras funções: representativa, descritiva, narrativa, simbólica, expressiva, estética, lúdica, conativa, metalinguística, fática (CAMARGO, 2019). A relação entre ilustração e o texto em questão possui coerência intersemiótica, denominação essa que amplia o conceito de coerência textual, uma vez que deseja mostrar uma convergência e não contradição entre os significados denotativos e conotativos da ilustração com o texto. Diante dessas possibilidades podemos analisar algumas das ilustrações. 
A primeira ilustração é de um anão. É interessante notar que não há anões no título desta tradução. Talvez fosse interessante ter a imagem da personagem principal, já que a narrativa de apresentação menciona o nome da princesa.

Imagem 1 - 0 anão na capa da história

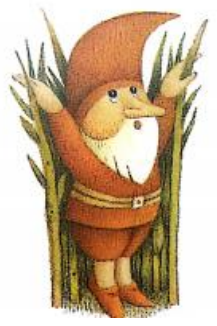

Fonte: Grimm e Grimm (1996).

Na página 49 pela primeira vez temos a personagem principal da trama. A imagem é carregada de cores e traços que parecem se misturar com a personagem. Referem-se ao ponto da história em que Branca de Neve é levada para a mata pelo caçador. Uma fita se entrelaça entre os braços da menina, como se estivesse amarrada a uma árvore. Ao fundo é possível notar uma casa perdida na floresta, o que sugestiona ser a casa dos sete anões. Logo em seguida eles aparecem no conto, com feições assustadas, possivelmente olhando para aquela menina enorme na frente deles.

Imagens 2 - Primeira aparição de Branca de Neve e anões assustados
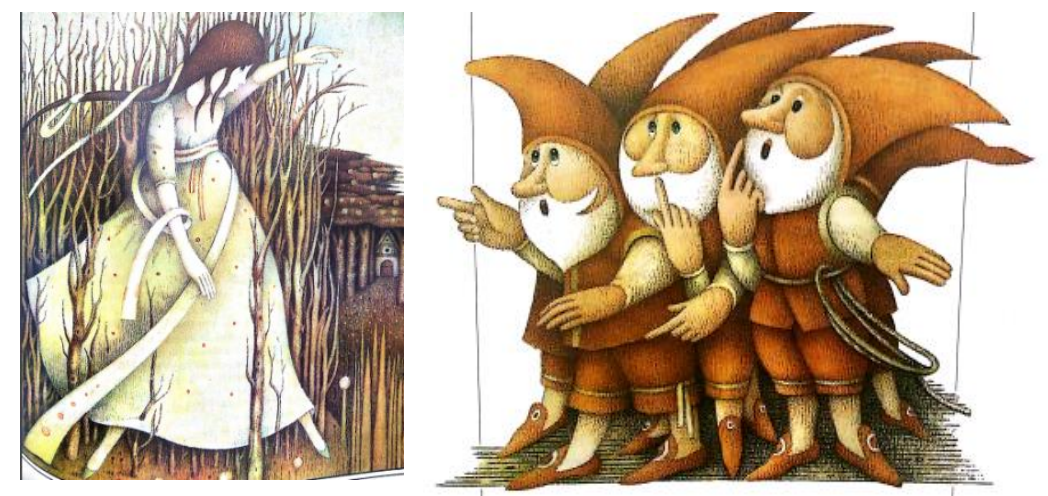

Fonte: Grimm e Grimm (1996, p. 49).

A imagem da página 55 nos remete à cena em que a rainha tenta matar Branca de Neve com uma fita, tentando sufocá-la. As ilustrações são sempre muito coloridas, contendo muito traços, deixando-as um pouco abstratas. 
Imagem 3 - Branca de Neve cai nas mãos da madrasta e os anões encontram Branca de Neve
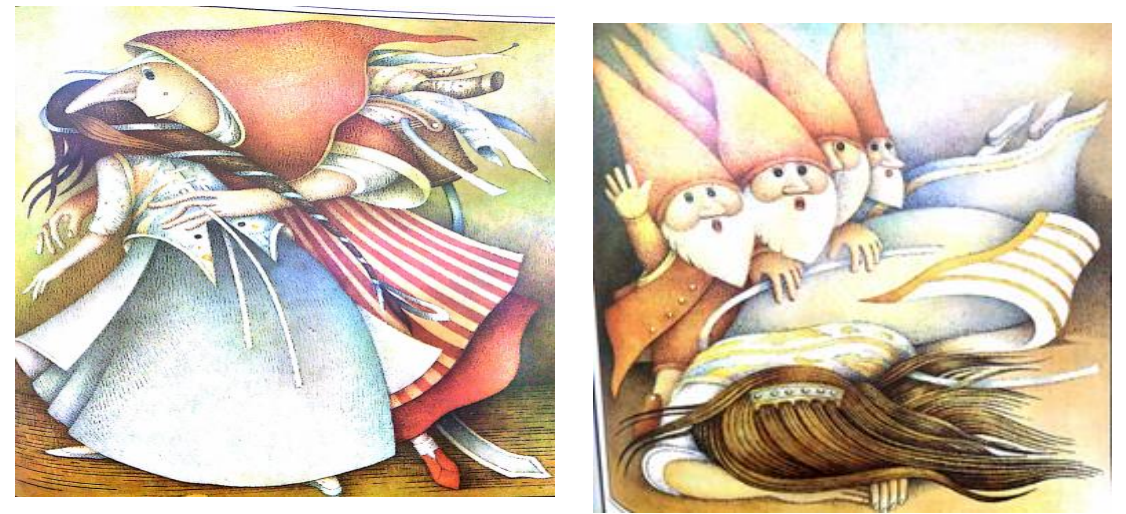

Fonte: Grimm e Grimm (1996, p. 55).

Na página 59 a rainha se disfarça novamente e leva uma maçã envenenada para tentar matar Branca de Neve. A ilustração é bem-feita e nos remete realmente a uma camponesa da época. Ao contrário das outras ilustrações, essa não tem muitas cores.

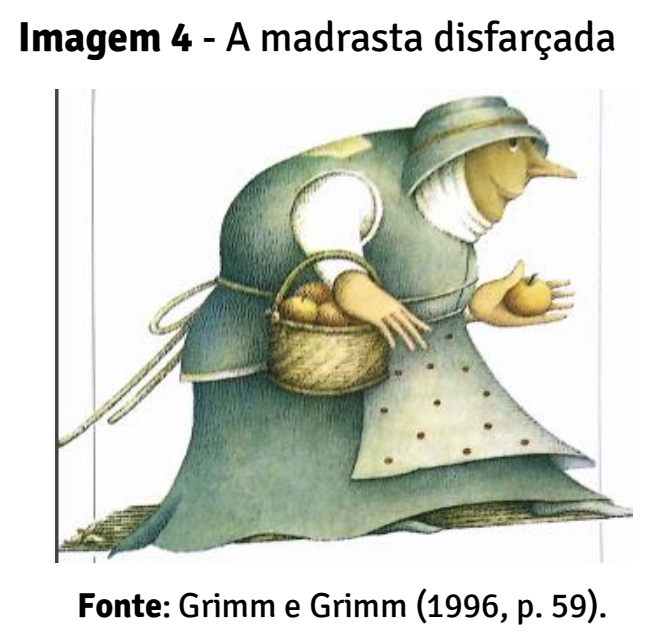

Ao fim, na página 63, temos referência ao casamento de Branca de Neve com o príncipe. A ilustração volta a ser bastante colorida, com muitos traços em vermelho, simbolizando a maturidade de Branca de Neve. Ao lado do casal aparecem os anões, felizes com o casamento em meio a um campo de flores. 
Imagem 5 - 0 casamento

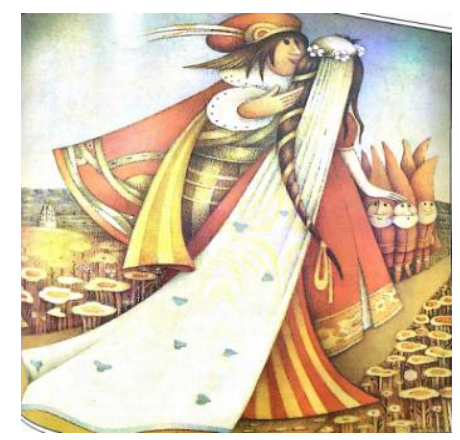

Fonte: Grimm e Grimm (1996, p. 63).

Nós, autoras do ensaio, entendemos que precisamos ainda mergulhar em águas profundas, mas ainda turvas para nós, em busca de degraus mais altos no mundo letrado, no que se refere aos critérios, saberes e valores para analisar imagens, mas temos certeza de que esse conhecimento produzido ao longo da história da humanidade, desde as pinturas em paredes de cavernas até a arte abstrata pós-moderna, poderia ampliar nosso conhecimento, que, neste caso, não bastaria saber apreciar imagens em um livro ou em uma pinacoteca, mas ler para conhecer a produção cultural de diferentes povos sobre as imagens construídas e seus efeitos. Diferentemente de nós, Bettelheim (1980) expressa em suas palavras um conhecimento profundo sobre a área em que escolheu analisar os contos de fadas.

Os irmãos Grimm em 1810 fizeram seu primeiro manuscrito reunindo diversos contos populares das províncias alemãs, anteriormente contados através da tradição oral. Inicialmente os contos faziam parte de histórias para os adultos, mas os irmãos adaptaram os contos para o universo infantil no livro Histórias das Crianças e do Lar. Entre os contos presentes no livro aparece a história da Branca de Neve. 0 livro leva em consideração a formação da educação moral da criança.

De acordo com Bettelheim (1980, p. 21), os Contos de Fadas possuem grande importância, porque abordam os problemas humanos cotidianos, como a inveja, a raiva, o ciúme, o egoísmo e a vingança: "Os contos de fadas lidam de forma imaginativa com as proposições mais importantes sobre o desenvolvimento em nossas vidas." Podemos relacionar Branca de Neve com a análise psicanalítica por meio da interpretação feita por Bettelheim (1980), que o relaciona ao Mito de Édipo, à antiga história grega sobre Édipo-rei escrita por Sófocles, cuja história trágica de um filho que se apaixona pela mãe inspirou diversos autores da psicanálise. Branca de Neve representa a criança no nível 
pré-edípico em desenvolvimento, e a madrasta toma a figura de mãe e o Rei a de pai. Como diz Bettelheim (1980 p. 27), “a história trata essencialmente dos conflitos edípicos entre mãe e filha na infância e finalmente na adolescência, dando maior ênfase ao que constitui uma infância feliz e o que é necessário para crescermos a partir dela”.

Ou seja, do ponto de vista da psicanálise o conto trata do conflito de Édipo entre mãe e filha, na relação de ciúmes e na competição da atenção do pai (BETTELHEIM, 1980, p. 29):

\begin{abstract}
Como a criança deseja ser amada pelos pais - fato bem conhecido, mas que é frequentemente negligenciado na discussão da situação edípica devido à natureza do problema - é muito ameaçador para ela imaginar que o amor de um dos pais por ele possa causar ciúmes no outro. Quando esse ciúme como no caso da rainha em 'Branca de Neve' - não pode ser ignorado, então é preciso encontrar alguma outra razão que o explique, o que na história é atribuído à beleza da menina.
\end{abstract}

$\mathrm{Na}$ história, a madrasta (mãe) é retratada como narcisista e extremamente preocupada com sua beleza, mas a partir do momento que começa a florescer a sexualidade de Branca de Neve, a Rainha passa a sentir ciúmes. Bettelheim (1980, p. 246) explica:

\begin{abstract}
A menina pequena acha a mãe a mulher mais linda do mundo, e é assim que o espelho fala inicialmente com a rainha. Mas como a menina mais velha considera-se muito mais bonita do que a mãe, isso o que o espelho diz mais adiante. A mãe pode se desencorajar quando se compara com a filha num espelho e pode pensar: - 'Minha filha é mais bonita que eu'. - Mas o espelho diz: - 'Ela é mil vezes mais linda' - uma afirmativa análoga ao exagero do adolescente que faz com que aumente suas vantagens e com isso silencie as dúvidas internas.
\end{abstract}

A história faz alusão a uma fase da vida da criança ao passar pela puberdade e como é o relacionamento dela com seus pais nesse tempo de transformação. Numa leitura freudiana, o conto, ao ser lido para a criança, a encoraja a superar os desafios do cotidiano.

Um pesquisador restrito a área da psicologia não conseguiria fazer essa relação. Freud era um leitor de mitologia grega, por isso as relações intertextuais o fizeram pensar o que pensou e por extensão o que Bettelheim nos apresenta. Quanto maior for a estrada do percurso de apropriação da cultura escrita, que proporciona sorver o máximo possível do que a humanidade já produziu nas diversas áreas, tanto maior serão as relações que conseguiremos tecer, criar e recriar. Os Grimm não estavam preocupados em escrever uma história edípica. São os percursos percorridos por Freud, nos livros 
escritos por outros homens e outras culturas e, na sequência Bettelheim, que fizeram pensar nessa possibilidade de interpretação. Freud pensou em Édipo-rei; Bettelheim pensou nos contos de fadas. Nós temos esses dois autores e tantos outros para impulsionar nosso processo de imersão nos discursos socialmente produzidos, que não terá um fim, inerente à própria natureza de processo, sempre em movimento e transformação.

\title{
Últimas explicações necessárias
}

Como vimos, no breve exemplo do conto Branca de Neve, o letramento não admite adjetivos. Não é possível escolher uma área do saber e ser letrado nela de forma dissociada de todos os outros saberes; a apropriação da escrita como processo inclui relações culturais, históricas e sociais de saberes e de valores que circulam na sociedade. Neste espaço, mostramos aspectos linguísticos, gráficos e intertextuais que envolvem o conto analisado, que envolvem registros escritos, mas que não quer dizer conhecer profundamente uma área, mas estabelecer relações entre áreas no âmbito da cultura escrita. 0 que queremos dizer é que uma pessoa não será considerada letrada por apenas conhecer os grandes clássicos da literatura infantil, mas por fazer desse conhecimento um outro produto, um outro discurso, mais profundo ou menos profundo. A criança pode nadar no raso, enquanto ganha confiança e fôlego para águas mais profundas.

É difícil classificar uma obra como literária ou não literária. Para isso, devemos, primeiramente, definir o que pode conter cada classificação. A busca por definições é longa, uma vez que há diversos autores que definem literatura a seu próprio modo, cada qual com sua interpretação. 0 debate torna-se ainda mais extenso ao tentarmos incluir literatura infantil como obras literárias ou didáticas. Coutinho (1978, p. 9-10) constrói desta forma o seu conceito de literatura:

\begin{abstract}
A literatura, como toda arte, é uma transfiguração do real, é a realidade recriada através do espírito do artista e retransmitida através da língua para as formas, que são os gêneros, e com os quais ela toma corpo e nova realidade. Passa, então, a viver outra vida, autônoma, independente do autor e da experiência de realidade de onde proveio. Os fatos que the deram às vezes origem perderam a realidade primitiva e adquiriram outra, graças à imaginação do artista. São agora fatos de outra natureza, diferentes dos fatos naturais objetivados pela ciência ou pela história ou pelo social.
\end{abstract}

Temos então uma definição simples e bastante satisfatória do que é literatura: uma transfiguração do real pelos olhos de um artista, no caso, um escritor. A história de 
Branca de Neve encaixa-se com facilidade nesta definição, acima de tudo por ser uma ficção com estreita ligação ao mundo encantado. Não importa se foi baseada ou não em algum fato. Sua essência e beleza é o que há de mais importante para o leitor. Tampouco importa determinar se foi escrita com 0 intuito de servir como um livro didático/pedagógico; não esboça um conteúdo escolar específico. Apesar de sua simbologia, Branca de Neve é, acima de tudo, uma narrativa, como diz Bettelheim (1980, p. 26-39):

\begin{abstract}
'Branca de Neve' é um dos contos de fadas mais conhecidos. Sua narrativa remonta a séculos, sob várias formas, em todos os países e línguas europeias; daí se disseminou para os outros continentes. [...] Poucos contos de fadas ajudam o ouvinte a distinguir as fases principais da infância de forma nítida como 'Branca de Neve' o faz. Os primeiros anos, de dependência pré-edípica absoluta, são mencionados levemente, como ocorre na maioria dos contos de fadas. A história trata essencialmente dos conflitos edípicos entre mãe e filha na infância e finalmente na adolescência, dando maior ênfase ao que constitui uma infância feliz e o que é necessário para crescermos a partir dela.
\end{abstract}

Bettelheim (1980) aborda o conto por meio de um olhar crítico, porque ele percebeu uma situação de competição entre uma madrasta e uma enteada. Esta demonstração faz alusão à discussão acerca da disputa entre mulheres, frequentemente fomentada em sociedades sexistas, com o intuito de impor uma realidade envolta em inveja que provoca uma profunda ausência de empatia mútua entre mulheres. As rivalidades são mecanismos capazes de união e de desagregação; nascem com e da marginalização. Em sociedades patriarcais, é comum que mulheres sejam rodeadas por uma falsa consciência, convencidas de que o inimigo é outra mulher, ao invés de combater este sistema de opressão.

Com sua pesada carga psicológica juntamente a seus possíveis aprendizados, Branca de Neve é, essencialmente, uma obra literária, uma das mais antigas e famosas histórias contadas pela civilização ocidental. Um cidadão letrado conhece essa obra! Depois de Bettelheim (1980), a conhecem como uma outra história por meio da leitura, um processo complexo e profundo, que torna um homem letrado. 


\section{Referências}

BETTELHEIM, B. A psicanálise dos contos de fadas. 9. ed. Rio de Janeiro: Paz e Terra, 1980.

CAMARGO, L. A relação entre imagem e texto na ilustração de poesia infantil. [São Paulo: Unicamp, 2019]. Disponível em:

https://www.unicamp.br/iel/memoria/Ensaios/poesiainfantilport.htm. Acesso em: 25 nov. 2019.

CHARAUDEAU, P.; MAINGUENEAU, D. Dictionnaired'analyse du discours. Paris: Seuil, 2002.

COUTINHO, A. Notas de teoria literária. 2. ed. Rio de Janeiro: Civilização Brasileira, 1978.

GRIMM, J.; GRIMM, W. Branca de Neve. In: GRIMM, J.; GRIMM, W. Contos de Grimm. São Paulo: Companhia das Letrinhas, 1996. v. 4, p. 47-63.

LANE, M. Picturing a rose: a way of looking at fairy tales. New York: H. W. Wilson, 1993.

LUBETSKY, M. J. The magic of fairy tales: psychodynamic and developmental perspectives. Child psychiatry and human development, New York, v. 19, n. 4, p. 245255, 1989.

ROBINSON, O. Rymes and reasons in the Grimms Kinder und hausmarchen. The German Quarterly, Philadelphia, v. 77, n. 1, p. 47-58, 2004.

SCHNEIDER, R. E. F.; TOROSSIAN, S. D. Contos de fadas: de sua origem à clínica contemporânea. Psicologia em Revista, Belo Horizonte, v. 15, n. 2, p. 132-148, ago. 2009. Disponível em: http://pepsic.bvsalud.org/pdf/per/v15n2/v15n2a09.pdf. Acesso em: 5 jul. 2018.

TOLKIEN, J. R. R. Árvore e folha. São Paulo: Martins Fontes, 2013. 